\title{
The COMPREHENSIVE HIGH ว̇CHOOL-IS IT STILL VIABLE?
}

pe failure of our high schools to rrve employment-bound youth annot be attributed to principals llone; neither will the restructuring if our high schools solve the roblem. But, says this writer, the rincipal is a key figure in the quation of quality and equity in ducation.

\section{iY RALPH C. WENRICH}

$N$ 1957, JAMES B. CONANT did a study to get an answer to the question, "Can a school at one and the same time provide a good general education for all the pupils as future citizens of a democracy, provide elective programs for the majority to develop useful skills, and educate adequately those with a talent for handling advanced academic subjects-particularly foreign languages and advanced mathematics?"

In 1959, Conant reported his findings in The American High School Today, subtitled A First Report to Interested Citizens.

Conant visited high schools in 18 states and identified the three main objectives of a comprehensive high school as, "first, to provide a good general education for all the future citizens; second, to provide good elective programs for those who wish to use their acquired skills immediately on gradua-

RALPH C. WENRICH is professor emeritus, University of Michigan, Ann Arbor. tion; third, to provide satisfactory programs for those whose vocations will depend on their subsequent education in a college or university."

Conant did a second report to interested citizens, titled The Comprehensive High School (1967), which was based on principals' responses to a questionnaire.

In the first chapter, Conant defined the comprehensive high school. He stated:

It is called comprehensive because it offers, under one roof (or a series of roofs), secondary education for almost all the high school age children of one town or neighborhood. It is responsible for educating the boy who will be an atomic scientist and the girl who will marry at eighteen; the prospective captain of a ship and the future captain of industry. It is responsible for educating the bright and the not so bright children with different vocational and professional ambitions and with various motivations. It is responsible, in sum, for providing good and appropriate education, both academic and vocational, for all young people within a democratic environment which the American people believe serves the principles they cherish.

After completing the second study, Conant stated, "I am prepared to maintain that an excellent comprehensive high school can be developed in any school district provided the school enrolls at least 750 students and sufficient funds are available. (Italics added.)

Since one of the three main objectives of the comprehensive high school is "to provide good elective programs for those who wish to use their acquired skills 
immediately on graduation," it is the purpose of this article to critically examine the extent to which this objective has been neglected, especially during this decade.

Partly because of federal interventions, the objective "to provide satisfactory programs for those whose vocations will depend on their subsequent education in a college or university" has received the major share of attention in most high schools in the United States.

\section{What Is General Curriculum?}

There is little disagreement with the idea that a comprehensive high school should "provide a good general education for all the pupils as future citizens of a democracy." There is still no agreement, however, as to the content of a general education program, or core curriculum, although Sizer, Goodlad, Boyer, and others have given much attention to this phase of the high school curriculum.

And, I assume that no one would disagree with the idea that a comprehensive high school should "educate adequately those with a talent for handling advanced academic subjects." But my thesis is that, during this decade, our high schools have become more concerned about the education of college-bound youth and in the process have neglected the employment-bound students.

Early in this decade, the then-secretary of education created the National Commission on Excellence in Education which produced the report titled $A$ Nation at Risk: The Imperative for School Reform. This report was severely critical of public secondary schools in the United States, and was followed by a number of other reports seeking "excellence." The Education Commission of the States (ECS) produced a report titled Action for Excellence. The ECS report was given wide publicity, and was reproduced, in total, by the National School Boards Association. As a result, boards of education all over the country took steps to improve instruction in our high schools.

For the most part, it was thought that schools could be improved by lengthening the school day and school year and by requiring students to take more academic subjects, those traditionally required for college-bound youth. These efforts may have helped to take the nation out of the "at risk" category, but they also have certainly helped to place in jeopardy those youth who will terminate their formal education upon graduation from high school or before.

One of the most comprehensive studies of the impact of the "excellence" movement was recently reported in $U p$ from Excellence by William W. Wayson and his colleagues (Phi Delta Kappa, 1988). Excellence is what American education is all about. Educators are not worthy of the name when they give up the pursuit of excellence for all students. Neither can educators default to any group the right to define excellenceparticularly any group that defines it in ways that exacerbate social class tension and systematically deny opportunity to youngsters from disadvantaged backgrounds.

\section{Excellence Movement Floundering}

The excellence movement is floundering because it has failed to understand 
what it takes to achieve it. Business as usual, as suggested by the authors of The Shopping Mall High School (Powell et al., Houghton Mifflin, 1985), is not enough. Excellence cannot be attained if educators ignore enduring public concerns about our schools. Attributes that characterize the best schools today must become the accepted standard for most schools tomorrow.

Ernest L. Boyer, in the January 1988 NASSP Bulletin, gave a test of quality against which the reform movement must be measured. Boyer listed four back-tobasic questions we now confront:

- Can we attract and hold outstanding teachers?

- Can we agree on the content to be taught?

- Can we effectively evaluate the students?

- Can we serve all children, not just the most advantaged?

If space permitted, I should like to discuss each of these questions, but my thesis relates directly to Boyer's fourth question, which is, that during our search for "excellence" most high schools in the United States have shown much more concern about the needs of college-bound students (the most advantaged) and in the process employment-bound youth have been neglected.

Chester Finn, former assistant secretary for research and development in the U.S. Department of Education, in an article in the Phi Delta Kappan (November 1986), stated, "A duel now underway in the education reform movement could needlessly wound some innocent victims: high school students who are not heading directly to college. The real interests of these youngsters could be jeopardized in the clash between those who demand a classical academic curriculum for all high school students and those who favor sticking doggedly to a multi-track system featuring vocational education for the non-college-bound."

Finn then goes on, "Those on each side offer compelling arguments for their points of view-arguing for a rigidly egalitarian approach ('all schooling should be identical') at one extreme and, at the other, for unbridled diversity and untrammeled freedom of choice. One side champions the goal of providing all students with the same lofty educational quality and rigorous expectations; the other warns that a common curriculum is ill advised for some youngsters; the handicapped, the seriously disadvantaged, and those who will enter the workforce or a technical training program directly after high school."

The excellence movement is floundering because it has faile to understand what it takes to achieve it.

Finn suggests the solution to this dilemma is ". . . what we in government sometimes call 'Option B,' a middle ground between two opposing points of view. This option consists of a curriculum that is at least 80 percent and perhaps 90 percent identical for collegebound and non-college-bound students. Most of what variety there is would be confined to the eleventh and twelfth grades. Of the 24 or so courses that a high school student might take in four years, only 3 or 4 would be significantly 
different for these two groups."

If Finn and his associates think this is a viable solution, we should all be concerned, not only about the future of atrisk students, but also about the role of the federal government in education.

A report titled The Forgotten Half: Non-College Youth in America, produced by the William T. Grant Foundation on Work, Family, and Citizenship (1988), makes the point that "It is now simply assumed that leaders and professionals in education, industry, and government will have a college education. But a college degree is not the only way to develop the talents of tomorrow's workers. For some it is far from the best. There are many opportunities outside the college classroom to develop skills and talents and many ways to contribute to a stronger America and to successful personal and family life that do not require a college degree."

The Ford Foundation final report states that "Our schools have become distracted from their main mission. Educators have become so preoccupied with those who go on to college that they have lost sight of those who do not. And more and more of the non-college-bound now fall between the cracks when they are in school; they drop out, or graduate but inadequately prepared for the requirements of the society and the workplace."

The Association for Supervision and Curriculum Development (ASCD) appointed a Task Force on Increased High School Graduation Requirements, and in 1985 published the report titled With Consequences for All. The report states that "Since A Nation At Risk was published in 1983, some 30 national reports and well over 300 state commis- sions have sustained the alleged weakness of high schools as a running news story. Most states have responded to the public demand for improvement by enacting legislation increasing the number of units in academic subjects required for graduation."

There are many opportunities outside the college classroom to develop skills and talents and many ways to contribute to a stronger America and to successful personal and family life that do not require a college degree.

The ASCD report recognizes that "today's students who go on to higher education will be more likely to have studied in areas that will help assure their success in college," but then adds, "Negative consequences are more likely for high school students who do not go to college. Although nearly three-fourths of today's students graduate from high school, this rate has dropped in recent years while the dropout rate has accelerated. Although this seems not to worry some reformers, it clearly runs counter to this country's goal of universal education. The thrust of reform must not be allowed to fade into another short-lived social cause that produces a spate of critical salvos and some secondary reshuffling, but no real solutions."

\section{No Shortage of Recommendations}

There has been no shortage of recom- 
mendations as to how excellence might be achieved. One could choose a course of action from any of several hundred reports identified by the Education Commission of the States (ECS) which appeared in the 1983-84 deluge.

Most reports dealt with higher standards. States and local school districts were urged to raise graduation requirements, eliminate some of the secondary school electives, lengthen the daily schedule and the annual calendar, test for promotion from grade to grade, and increase college admission standards. The elimination of electives-including vocational and practical arts courseshas adversely affected the employmentbound youth in our high schools.

Donald C. Orlich wrote, in an article in the Phi Delta Kappan (March 1989), "This nation has wasted billions of dollars on poorly conceived but politically popular reforms that have sapped the energies of schoolpeople." He believes that we need a moratorium on reforms so that educators and local policymakers can analyze their own problems. He suggests that this could lead to a new concept-local system analysis. "Each local school district would systematically study its own cultures-yes, culturesand then implement a carefully researched, well-coordinated, and wellfunded plan for specific improvements."

\section{A Neglected Goal}

The problem has been stated, and it now appears clear that one of the goals of the comprehensive high school, as defined by Conant, has been seriously neglected during this decade. Half the youth in our high schools have been cheated because our public schools have been preoccupied with the needs of college-bound students. These neglected youth include dropouts, pushouts, castoffs, and other casualties. They also include those who stayed in school long enough to graduate, but were prepared for neither college nor employment.

Since the comprehensive high school seemed to be such a good idea 30 years ago, and we still like to call many of our public high schools by this designation, what can be done to revive it so that the goals can be achieved?

The internal administrative structures of our high school should be reexamined. Many comprehensive high schools have been accused of "tracking" students by placing them in one of several curricula offered: the college preparatory, the vocational, or the general curriculum.

The general curriculum has come in for most of the criticism, because students who had not planned on continuing their education beyond high school and those who had no post-high-school career plans were frequently counseled into the general curriculum.

Rupert N. Evans, in Foundations of Vocational Education (1971), wrote "The general curriculum in the secondary school has so little to commend it that it is sure to disappear. Both the vocational and the college preparatory curricula are expanding slowly and this expansion comes at the expense of the general curriculum; it has by far the highest dropout rate of the present three high school curricula and has by far the lowest rate of college attendance by its graduates." It seems clear that the general curriculum, as such, should be eliminated (where it still exists). But what else can be done 
by way of restructuring?

The comprehensive high schools should adopt a bifurcated system in which there would be two main branches-schools within a school---each with a separate faculty, and each headed by an assistant principal to give instructional leadership and ensure articulation between these two major units. This type of administrative structure would be similar to that found in many colleges and universities, where students are enrolled in a liberal arts curriculum until they are ready for a professional school.

\section{Half the youth in our high schools have been cheated because our public schools have been preoccupied with the needs of college-bound students.}

This "branching" should occur after the completion of the "common learnings" or the "core curriculum," which, for most students, would be after completing the tenth grade, and a point at which most students would be 16 years of age. These two branches might appropriately be designated the "collegeprep branch" and the "tech-prep branch." The faculty and staff of the tech-prep programs would develop a variety of cooperative training programs through close working relationships with businesses and industries in the community.

\section{Principal the Key Figure}

Failure of our high schools to serve employment-bound youth cannot be attributed to high school principals alone; neither will the restructuring of our high schools solve the problem. But, by any criterion one might use, the high school principal is a key figure in the equation of both quality and equity in education.

The high school principal should serve as the instructional leader as well as the administrator. And since leadership is a shared responsibility he or she must have the enthusiastic support of faculty and staff.

John W. Gardner, in an article in the NASSP Bulletin (April 1989), titled "Leadership: The Task of Motivating," wrote:

The tasks of the leader with respect to motivation are many and varied. Among other things, a leader must recognize the needs of followers or constituents, help them see how these needs can be met, and give them the confidence that they can accomplish that result through their own efforts. ... The annals of management are filled with tales of the vigorous leader who moves in to head a moribund unit and turns it into a lively group without resorting to any change in personnel. It is not uncommon that inside a mediocre performer is an excellent performer awaiting liberation.

Any high school principal who has not read Gardner's book, ExcellenceCan We Be Equal and Excellent Too, should do so immediately. In both the original issue of this book, published in 1961 (Harper and Brothers), and the revised edition published in 1984 (Norton), Gardner states:

We must learn to honor excellence in every socially accepted human activity, however humble the activity, and to scorn shoddiness, however exalted the activity. An excellent plumber is infinitely more 
admirable than an incompetent philosopher. The society which scorns excellence in plumbing because plumbing is a humble activity and tolerates shoddiness in philosophy because it is an exalted activity will have neither good plumbing nor good philosophy. Neither its pipes nor its theories will hold water.

If we expect principals and their faculty members to achieve the goals of the comprehensive high school, they must be given the authority (empowered) by their boards of education and their superintendents to identify school leadership as the most important aspect in the quality of learning in a school. Legislation may be needed, in some states, to more clearly define the role of principal and support his or her leadership.

High school principals must be able to choose their own faculty members and retain only those that they want. They also need discretionary money for special projects and a system of incentives to reward the excellent teachers. Collective bargaining agreements that limit the authority of the principal in making committee assignments to work on curriculum problems, or put a limit on the number of faculty meetings a principal may call, should not be tolerated.

Principals, particularly those who claim to have comprehensive high schools, must allocate a substantial portion of their time to the development of their constituencies in the community; these include parents, taxpayers, community leaders, and-if the school is to serve employment-bound youth-one of the most important groups of constituents would be employers in business and industry. Developing good relationships with local businesses and industries is not a function that can be delegated to someone in the superintendent's office; these functions must be carried out on a daily basis by principals and their staff.

We have tried federal proposals for renewal of our high schools. Now let us make local school districts and particularly the comprehensive high school principals and their faculties responsible.

In NASSP's The Senior High School Principalship, Vol. II, it was stated that one major conclusion which could be drawn from the study was that "... the majority of principals interviewed are hardworking, dedicated individuals, concerned about students and involved in improving opportunities for learning in their schools."

It must be assumed that our senior high principals are interested in both quality and equity. And furthermore, it must also be assumed that they are concerned about the future of both the college-bound and the employmentbound youth.

\section{It Happened in February}

1861: Jefferson Davis was inaugurated as President of the Confederate States of America in Montgomery, Alabama.

1899: The United States Senate gave its consent to the Treaty of Paris.

1913: The Sixteenth Amendment was ratified.

1933: The Twentieth Amendment was ratified. 